\title{
Papers
}

\section{Corticosteroids for severe sepsis and septic shock: a systematic review and meta-analysis}

\author{
Djillali Annane, Eric Bellissant, Pierre Edouard Bollaert, Josef Briegel, Didier Keh, Yizhak Kupfer
}

\begin{abstract}
Objective To assess the effects of corticosteroids on mortality in patients with severe sepsis and septic shock.

Data sources Randomised and quasi-randomised trials of corticosteroids versus placebo (or supportive treatment alone) retrieved from the Cochrane infectious diseases group's trials register, the Cochrane central register of controlled trials, Medline, Embase, and LILACS.

Review method Two pairs of reviewers agreed on eligibility of trials. One reviewer entered data on to the computer and four reviewers checked them. We obtained some missing data from authors of trials and assessed methodological quality of trials. Results $16 / 23$ trials $(n=2063)$ were selected. Corticosteroids did not change 28 day mortality ( 15 trials, $n=2022$; relative risk $0.92,95 \%$ confidence interval 0.75 to 1.14 ) or hospital mortality (13 trials, $\mathrm{n}=1418 ; 0.89,0.71$ to 1.11 ). There was significant heterogeneity. Subgroup analysis on long courses ( $\geq 5$ days) with low dose ( $\leq 300 \mathrm{mg}$ hydrocortisone or equivalent) corticosteroids showed no more heterogeneity. The relative risk for mortality was 0.80 at 28 days (five trials, $\mathrm{n}=465 ; 0.67$ to 0.95 ) and 0.83 at hospital discharge (five trials, $\mathrm{n}=465,0.71$ to 0.97 ). Use of corticosteroids reduced mortality in intensive care units (four trials, $\mathrm{n}=425,0.83,0.70$ to 0.97 ), increased shock reversal at 7 days (four trials, $\mathrm{n}=425 ; 1.60,1.27$ to 2.03 ) and 28 days (four trials, $\mathrm{n}=425,1.26,1.04$ to 1.52 ) without inducing side effects. Conclusions For all trials, regardless of duration of treatment and dose, use of corticosteroids did not significantly affect mortality. With long courses of low doses of corticosteroids, however, mortality at 28 days and hospital morality was reduced.
\end{abstract}

\section{Introduction}

Each year severe sepsis occurs in about three people per 1000 population and accounts for $2 \%$ of hospital stays. ${ }^{1}$ About $3 \%$ of such patients will develop septic shock, ${ }^{2}$ which itself accounts for $10 \%$ of stays in intensive care units. ${ }^{3}$ Overall, hospital mortality is $30 \%$ for severe sepsis and $50-60 \%$ for septic shock. ${ }^{1-3}$

Researchers have explored the biological mechanisms of septic shock for potential interventions. Corticosteroids have been tested because of their interactions with immune responses. ${ }^{4}$ Indeed, these hormones affect inflammation through their effects on white blood cells, cytokines, and nitric oxide production. However, cytokines may suppress the cortisol response to the adrenocorticotropin hormone, causing poor adrenal activity, ${ }^{5}$ and body tissues may become resistant to corticosteroids. ${ }^{6}$ The prevalence of adrenal insufficiency in septic shock is about $50 \%$. For these reasons, it has been anticipated that corticosteroids could be beneficial in septic shock.
Initial studies with corticosteroids in sepsis and septic shock used short courses of high doses. They did not show any evidence of benefit, as shown by two meta-analyses of the randomised trials published during the period 1966-93. ${ }^{78}$ However, these reviews did not exclude a benefit of longer durations of treatment ( $\geq 5$ days) and lower doses $(\leq 300 \mathrm{mg}$ hydrocortisone or equivalent a day), as observed in more recent trials. ${ }^{9-14} \mathrm{We}$ systematically reanalysed the effects of corticosteroids in severe sepsis and septic shock, considering all currently available data.

\section{Methods}

\section{Studies and participants}

We searched for randomised or quasi-randomised trials, with or without blinding, on severe sepsis and septic shock in children or adults. ${ }^{15}$ We included data from trials in sepsis, sepsis syndrome, or acute respiratory distress syndrome if separate data were available for septic shock.

\section{Interventions}

We considered all studies reporting on intravenous treatment with any corticosteroid preparation (for example, cortisone, hydrocortisone, methylprednisolone, betamethasone, or dexamethasone). We defined length of treatment at full doses as long ( $\geq 5$ days) or short ( $<5$ days) and classified daily doses of corticosteroids as low ( $\leq 300 \mathrm{mg}$ of hydrocortisone or equivalent) or high (>300 mg).

The control group received a standard treatment (that is, antibiotics, fluid replacement, inotropes or vasopressors, mechanical ventilation, renal replacement therapy), given either alone or with a placebo.

Table 1 Characteristics of studies excluded from meta-analysis of corticosteroids for patients with severe sepsis or septic shock

\begin{tabular}{|c|c|}
\hline Study & Reason for exclusion \\
\hline Hahn $1951^{18}$ & $\begin{array}{l}\text { Patients with acute streptococcal infections but not septic shock. Trial } \\
\text { investigated effect of hydrocortisone on fever, anti-streptolysin titres, } \\
\text { and onset of rheumatic fever. No data are reported for analysis of } \\
\text { various outcomes considered in systematic review }\end{array}$ \\
\hline Hughes $1984^{26}$ & $\begin{array}{l}\text { Only acute effects (within } 1 \text { hour) of methylprednisolone and/or } \\
\text { naloxone on haemodynamic data were available, and no data reported } \\
\text { for any outcomes considered in systematic review }\end{array}$ \\
\hline McKee $1983^{25}$ & $\begin{array}{l}\text { Mixed population of critically ill patients. Separate data from septic } \\
\text { shock not available }\end{array}$ \\
\hline Meduri $1998^{34}$ & $\begin{array}{l}\text { Trial included patients with late acute respiratory distress syndrome } \\
\text { phase and not patients with septic shock }\end{array}$ \\
\hline Rogers $1970^{21}$ & $\begin{array}{l}\text { Study published only as abstract, no contact with authors possible, } \\
\text { incomplete information for primary and secondary outcomes }\end{array}$ \\
\hline Thompson $1976^{12}$ & $\begin{array}{l}\text { Study published only as abstract, no contact with authors possible, } \\
\text { incomplete information for primary and secondary outcomes }\end{array}$ \\
\hline Weigelt $1985^{29}$ & $\begin{array}{l}\text { Mixed population of critically ill patients. Separate data from septic } \\
\text { shock not available }\end{array}$ \\
\hline
\end{tabular}




\begin{tabular}{|c|c|c|c|c|}
\hline Study & Design & Patients & Interventions & Outcomes \\
\hline Annane $2002^{12}$ (France) & $\begin{array}{l}2 \text { parallel groups, } \\
19 \text { centres }\end{array}$ & $\begin{array}{l}300 \text { adults with vasopressor and ventilator } \\
\text { dependent septic shock }\end{array}$ & $\begin{array}{l}\text { Hydrocortisone ( } 50 \mathrm{mg} \text { intravenous bolus } \\
\text { every } 6 \mathrm{~h} \text { for } 7 \text { days + fludrocortisone } 50 \\
\mu \mathrm{g} \text { taken orally every } 24 \mathrm{~h} \text { for } 7 \text { days); } \\
\text { respective placebos. Treatments had to be } \\
\text { initiated within } 8 \mathrm{~h} \text { from shock onset }\end{array}$ & $\begin{array}{l}\text { Primary: } 28 \text { day mortality in } \\
\text { non-responders } \\
\text { Secondary: } 28 \text { day mortality in responders } \\
\text { and all patients; ICU mortality; hospital } \\
\text { mortality; } 1 \text { year mortality; shock reversal; } \\
\text { organ system failure free days; safety }\end{array}$ \\
\hline Bollaert $1998^{9}$ (France) & $\begin{array}{l}2 \text { parallel groups, } \\
2 \text { centres }\end{array}$ & $\begin{array}{l}41 \text { adults with vasopressor and ventilator } \\
\text { dependent septic shock }\end{array}$ & $\begin{array}{l}\text { Hydrocortisone ( } 100 \mathrm{mg} \text { intravenous bolus } \\
\text { every } 8 \mathrm{~h} \text { for } 5 \mathrm{~d} \text { then tapered over } 6 \mathrm{~d}) \text {; } \\
\text { placebo. Treatments had to be initiated } \\
\text { after } 48 \mathrm{~h} \text { or more from shock onset }\end{array}$ & $\begin{array}{l}\text { Primary: shock reversal } \\
\text { Secondary: } 28 \text { day mortality; improvement } \\
\text { in haemodynamics; safety }\end{array}$ \\
\hline Bone $1987^{30}$ (US) & $\begin{array}{l}2 \text { parallel groups, } \\
19 \text { centres }\end{array}$ & $\begin{array}{l}382 \text { adults with severe sepsis }(n=234) \text { or } \\
\text { septic shock }(n=148)\end{array}$ & $\begin{array}{l}\text { Methylprednisolone }(30 \mathrm{mg} / \mathrm{kg} 20 \mathrm{~min} \\
\text { intravenous infusion, every } 6 \mathrm{~h} \text { for } 24 \mathrm{~h}) \text {; } \\
\text { placebo. Treatments had to be initiated } 2 \mathrm{~h} \\
\text { from time entry criteria were met }\end{array}$ & $\begin{array}{l}\text { Primary: } 14 \text { day development of shock for } \\
\text { severe sepsis; shock reversal for septic } \\
\text { shock; } 14 \text { day death and safety }\end{array}$ \\
\hline Briegel $1999^{10}$ (Germany) & $\begin{array}{l}2 \text { parallel groups, } \\
1 \text { centre }\end{array}$ & $\begin{array}{l}40 \text { adults with vasopressor and ventilator } \\
\text { dependent septic shock }\end{array}$ & $\begin{array}{l}\text { Hydrocortisone ( } 100 \mathrm{mg} 30 \mathrm{~min} \\
\text { intravenous infusion followed by } 0.18 \\
\mathrm{mg} / \mathrm{kg} / \mathrm{h} \text { continuous infusion until shock } \\
\text { reversal and then tapered off); placebo. } \\
\text { Treatments had to be initiated within } 72 \mathrm{~h} \\
\text { from shock onset }\end{array}$ & $\begin{array}{l}\text { Primary: shock reversal } \\
\text { Secondary: } 28 \text { day mortality; improvement } \\
\text { in haemodynamics; organ system failure; } \\
\text { safety }\end{array}$ \\
\hline Chawla $1999^{11}$ (US) & $\begin{array}{l}2 \text { parallel groups, } \\
1 \text { centre }\end{array}$ & $\begin{array}{l}44 \text { adults with vasopressor dependent } \\
\text { septic shock }\end{array}$ & $\begin{array}{l}\text { Hydrocortisone ( } 100 \mathrm{mg} \text { intravenous bolus } \\
\text { every } 8 \mathrm{~h} \text { for } 3 \text { days then tapered over } 4 \\
\text { days); placebo. Treatments had to be initiated } \\
\text { after } 72 \mathrm{~h} \text { or more from shock onset }\end{array}$ & $\begin{array}{l}\text { Primary: shock reversal } \\
\text { Secondary: } 28 \text { day mortality; improvement } \\
\text { in haemodynamics; safety }\end{array}$ \\
\hline CSG $1963^{20}$ (US) & $\begin{array}{l}2 \text { parallel groups, } \\
5 \text { centres }\end{array}$ & $\begin{array}{l}194 \text { adults and } 135 \text { children with } \\
\text { vasopressor dependent septic shock }\end{array}$ & $\begin{array}{l}\text { Hydrocortisone (intravenous infusion of } \\
300 \mathrm{mg} \text { for } 24 \mathrm{~h} \text { then } 250 \mathrm{mg} \text { for } 24 \mathrm{~h} \text {, } \\
\text { followed by } 200 \mathrm{mg} \text { orally on day } 3 \text {, then } \\
\text { tapered off in steps of } 50 \mathrm{mg} / \text { day - that is, } \\
\text { total duration of treatment } 6 \text { days); placebo }\end{array}$ & $\begin{array}{l}\text { Primary: hospital mortality } \\
\text { Secondary: safety }\end{array}$ \\
\hline Keh $2003^{14}$ (Germany) & Crossover design & $\begin{array}{l}40 \text { adults with vasopressor dependent } \\
\text { septic shock }\end{array}$ & $\begin{array}{l}\text { Hydrocortisone (100 mg } 30 \mathrm{~min} \text { intravenous } \\
\text { infusion followed by } 10 \mathrm{mg} / \mathrm{h} \text { continuous } \\
\text { infusion for } 3 \text { days); placebo. All patients } \\
\text { received hydrocortisone for } 3 \text { days preceded } \\
\text { or followed by placebo for } 3 \text { days }\end{array}$ & $\begin{array}{l}\text { Primary: immune response. } \\
\text { Secondary: improvement in } \\
\text { haemodynamics and organ system failure; } \\
\text { safety }\end{array}$ \\
\hline Klastersky ${ }^{23} 1971$ (Belgium) & $\begin{array}{l}2 \text { parallel groups, } \\
1 \text { centre }\end{array}$ & $\begin{array}{l}85 \text { adults with disseminated cancer and life } \\
\text { threatening infection }\end{array}$ & $\begin{array}{l}\text { Betamethasone }(1 \mathrm{mg} / \mathrm{kg} / \text { day in } 2 \\
\text { intravenous doses for } 3 \text { consecutive days); } \\
\text { placebo }\end{array}$ & 30 day mortality; rate of adverse events \\
\hline Lucas $1984^{27}$ (US) & $\begin{array}{l}2 \text { parallel } \\
\text { groups, } 1 \text { centre }\end{array}$ & 48 adults with septic shock & $\begin{array}{l}\text { Dexamethasone }(2 \mathrm{mg} / \mathrm{kg} \text { as a single } \\
\text { intravenous bolus followed a maintenance } \\
\text { infusion of } 2 \mathrm{mg} / \mathrm{kg} / 24 \mathrm{~h} \text { for } 2 \text { days); } \\
\text { standard treatment }\end{array}$ & $\begin{array}{l}\text { Primary: } 14 \text { day mortality (unclear) } \\
\text { Secondary: improvement in } \\
\text { haemodynamics; improvement in } \\
\text { pulmonary function; safety }\end{array}$ \\
\hline Luce $1988^{32}$ & $\begin{array}{l}2 \text { parallel groups, } \\
1 \text { centre }\end{array}$ & 75 adults with septic shock & $\begin{array}{l}\text { Methylprednisolone ( } 30 \mathrm{mg} / \mathrm{kg} 15 \mathrm{~min} \\
\text { intravenous infusion, every } 6 \mathrm{~h} \text { for } 24 \mathrm{~h} \text { ); } \\
\text { placebo }\end{array}$ & $\begin{array}{l}\text { Primary: prevention of acute respiratory } \\
\text { distress syndrome } \\
\text { Secondary: hospital mortality }\end{array}$ \\
\hline Schumer $1976^{24}$ (US) & $\begin{array}{l}3 \text { parallel groups, } \\
1 \text { centre }\end{array}$ & $\begin{array}{l}172 \text { adults with septic shock with positive } \\
\text { blood cultures }\end{array}$ & $\begin{array}{l}\text { Dexamethasone ( } 3 \mathrm{mg} / \mathrm{kg} \text { as a single } \\
\text { intravenous bolus); methylprednisolone ( } 30 \\
\mathrm{mg} / \mathrm{kg} \text { as a single intravenous bolus); } \\
\text { placebo. Treatments might have been } \\
\text { repeated once after } 4 \mathrm{~h} \text { and had to be } \\
\text { initiated at time of diagnosis }\end{array}$ & $\begin{array}{l}\text { Primary: } 28 \text { day mortality } \\
\text { Secondary: complications rates }\end{array}$ \\
\hline $\begin{array}{l}\text { Slusher } 1996^{33} \text { (US, Kenya, } \\
\text { Nigeria) }\end{array}$ & $\begin{array}{l}2 \text { Parallel groups, } \\
2 \text { centres }\end{array}$ & $\begin{array}{l}72 \text { African children aged } 1 \text { to } 16 \text { years with } \\
\text { severe sepsis or septic shock }\end{array}$ & $\begin{array}{l}\text { Dexamethasone }(0.20 \mathrm{mg} / \mathrm{kg} \text { every } 8 \mathrm{~h} \text { for } \\
2 \text { days); placebo. Treatments might have } \\
\text { been repeated once after } 4 \mathrm{~h} \text { if shock } \\
\text { persisted and had to be initiated } 5-10 \mathrm{~min} \\
\text { before first dose of antibiotic }\end{array}$ & $\begin{array}{l}\text { Primary: hospital mortality (unclear) } \\
\text { Secondary: haemodynamic stability at } 48 \mathrm{~h} \text {; } \\
\text { complications }\end{array}$ \\
\hline Sprung $1984^{28}$ (US) & $\begin{array}{l}3 \text { parallel groups, } \\
2 \text { centres }\end{array}$ & $\begin{array}{l}59 \text { adults with vasopressor dependent } \\
\text { septic shock }\end{array}$ & $\begin{array}{l}\text { Dexamethasone ( } 6 \mathrm{mg} / \mathrm{kg} \text { as a single } \\
\text { intravenous } 10 \text { to } 15 \mathrm{~min} \text { infusion); } \\
\text { methylprednisolone ( } 30 \mathrm{mg} / \mathrm{kg} \text { as a single } \\
\text { intravenous } 10 \text { to } 15 \mathrm{~min} \text { infusion); no } \\
\text { treatment; placebo. Treatments might have } \\
\text { been repeated once after } 4 \mathrm{~h} \text { if shock } \\
\text { persisted and had to be initiated at time of } \\
\text { diagnosis }\end{array}$ & $\begin{array}{l}\text { Primary: hospital mortality; shock reversal } \\
\text { Secondary: complications of septic shock; } \\
\text { treatments' safety }\end{array}$ \\
\hline VASSCSG $1987^{31}$ (US) & $\begin{array}{l}2 \text { parallel groups, } \\
10 \text { centres. }\end{array}$ & $\begin{array}{l}223 \text { adults with severe sepsis or septic } \\
\text { shock }(n=100)\end{array}$ & $\begin{array}{l}\text { Methylprednisolone ( } 30 \mathrm{mg} / \mathrm{kg} \text { as a single } \\
\text { intravenous } 10-15 \mathrm{~min} \text { infusion, followed } \\
\text { by a constant infusion of } 5 \mathrm{mg} / \mathrm{kg} / \mathrm{h} \text { for } 9 \\
\mathrm{~h} \text { ); placebo. Treatments had to be initiated } \\
\text { within } 2 \mathrm{~h}\end{array}$ & $\begin{array}{l}\text { Primary: } 14 \text { day mortality } \\
\text { Secondary: complications }\end{array}$ \\
\hline Wagner $1955^{19}(\text { US })^{*}$ & $\begin{array}{l}2 \text { parallel groups, } \\
2 \text { centres }\end{array}$ & $\begin{array}{l}113 \text { adults with pneumococcal pneumonia; } \\
\text { shock present in only } 3\end{array}$ & $\begin{array}{l}\text { Hydrocortisone (orally } 80 \mathrm{mg} \text { on admission } \\
\text { followed by } 60 \mathrm{mg} 3 \text { times on day } 1 \text {, then } \\
40 \mathrm{mg} 4 \text { times on day } 2,20 \mathrm{mg} 4 \text { times on } \\
\text { day } 3,10 \mathrm{mg} 4 \text { times on day } 4 \text {, and } 10 \mathrm{mg} \\
\text { twice on day 5); standard therapy (first } 85 \\
\text { patients); placebo (last } 28 \text { patients) }\end{array}$ & Fever; pleuritic pains; patient's wellbeing \\
\hline Yildiz 2002 $2^{13}$ (Turkey) & $\begin{array}{l}2 \text { parallel groups, } \\
1 \text { centre }\end{array}$ & $\begin{array}{l}40 \text { adults with sepsis }(n=14) \text {, severe sepsis } \\
(n=17) \text {, and septic shock }(n=9)\end{array}$ & $\begin{array}{l}\text { Prednisolone (2 intravenous bolus, } 5 \mathrm{mg} \text { at } \\
6 \text { am and } 2.5 \mathrm{mg} \text { at } 18 \mathrm{pm} \text { for } 10 \text { days); } \\
\text { placebo }\end{array}$ & $\begin{array}{l}\text { Primary: } 28 \text { day mortality } \\
\text { Secondary: complications }\end{array}$ \\
\hline
\end{tabular}

CSG=Cooperative Study Group; VASSCSG=Veterans Administration Systemic Sepsis Cooperative Study Group.

${ }^{*}$ Quasi-randomisd. 
Table 3 Assessment of methodological quality of studies with Cronin et al's "methodologic quality form" *8

\begin{tabular}{|c|c|c|c|c|c|c|c|c|c|c|c|c|}
\hline Study & 1 & 2 & 3 & 4 & 5 & 6 & 7 & 8 & 9 & 10 & 11 & Total (14.50) \\
\hline Wagner $1955^{19}$ & 0.5 & 0.5 & 1 & 0 & 2 & 0 & 0 & 0.5 & 0 & 0 & 0 & 4.5 \\
\hline CSG $1963^{20}$ & 0 & 0 & 2 & 0 & 2 & 0 & 0 & 0.5 & 0 & 0 & 0 & 4.5 \\
\hline Klasterski $1971^{23}$ & 0 & 0.5 & 2 & 2 & 2 & 0 & 1 & 0 & 0 & 0 & 0.5 & 8.0 \\
\hline Schumer $1976^{24}$ & 0.5 & 0.5 & 1 & 0 & 2 & 0 & 1 & 0.5 & 0 & 0 & 0.5 & 6.0 \\
\hline Lucas $1984^{27}$ & 0 & 0.5 & 1 & 0 & 2 & 0 & 1 & 0 & 1 & 0 & 0.5 & 6.0 \\
\hline Sprung $1984^{28}$ & 0.5 & 1 & 2 & 0 & 2.5 & 0 & 1 & 0.5 & 0 & 0 & 1 & 8.5 \\
\hline Bone $1987^{30}$ & 0.5 & 1 & 2 & 2 & 2.5 & 0 & 1 & 0.5 & 0 & 1 & 0.5 & 11.0 \\
\hline VASSCSG $1987^{31}$ & 1 & 1 & 2 & 2 & 2.5 & 1 & 1 & 1 & 1 & 1 & 0.5 & 14.0 \\
\hline Luce $1988^{32}$ & 1 & 1 & 2 & 2 & 2.5 & 0 & 1 & 1 & 0 & 0.5 & 0.5 & 11.5 \\
\hline Slusher $1996^{33}$ & 0.5 & 1 & 2 & 2 & 2.5 & 0 & 1 & 0.5 & 0 & 0 & 0.5 & 10 \\
\hline Bollaert $1998^{9}$ & 0.5 & 1 & 2 & 2 & 2.5 & 1 & 1 & 1 & 1 & 1 & 1 & 14 \\
\hline Briegel $1999^{10}$ & 0.5 & 1 & 2 & 2 & 2.5 & 1 & 1 & 1 & 1 & 1 & 1 & 14 \\
\hline Chawla 199911 & 0.5 & 1 & 2 & 2 & 2.5 & 1 & 1 & 0.5 & 0 & 1 & 1 & 12.5 \\
\hline Annane $2002^{12}$ & 1 & 1 & 2 & 2 & 2.5 & 1 & 1 & 1 & 1 & 1 & 1 & 14.5 \\
\hline Yildiz $2002^{13}$ & 0.5 & 1 & 2 & 2 & 2.5 & 0 & 1 & 0.5 & 0 & 0 & 0.5 & 10 \\
\hline Keh $2003^{14}$ & 0.5 & 1 & 2 & 2 & 2.5 & 1 & 1 & 1 & 1 & 1 & 1 & 14 \\
\hline
\end{tabular}

CSG=Cooperative Study Group; VASSCSG=Veterans Administration Systemic Sepsis Cooperative Study Group.

*Assessment of quality with scores in parentheses. 1=Patient selection: all eligible patients with number of and reason for exclusions given (1); attempt to do so, but reasons for failure and exclusion not given (0.5); selected patients/eligible patients not described (0). 2=Patients characteristics at baseline: diagnosis/similar distribution between groups reported (0.50), not reported (0): severity of illness $<10 \%$ difference between groups reported (0.50), not reported (0). $3=$ Randomisation: concealed randomisation (computer, centralised, etc (2): potentially manipulable (sealed envelope, date of admission, medical records, birth date, etc (1); can't tell (0). 4=Blinding: double blind (at least 2 of physicians, outcome analyst, patients) (2); single blinded (1); unblinded/can't tell ( 0 ). $5=$ Intervention: drug described explicitly-yes $(0.50)$, no $(0)$; dosing regimen (dose, frequency) reported $(0.50)$, not reported $(0)$; onset of treatment after development of sepsis reported ( 0.50$)$, not reported $(0)$; duration of treatment reported $(0.50)$, not reported $(0)$; placebo reported $(0.50)$, not reported $(0)$. $6=$ Contamination: reported $(1)$, not reported $(0)$. $7=$ Cointervention: reported (1); not reported (0). 8=Explicit description of complications: any three of secondary infection, gastroduodenal bleeding, organ system failure, hyperglycaemia (1); any two of those complications (0.5); 1 complication or none (0). 9=Withdrawal: described number and reason for withdrawal (1); described one of above (0.50); described neither (0). 10=Intention to treat and adherence to protocol: both reported (1), one reported (0.50), none reported (0). 11=Explicit definition: of septic shock (vasopressors dependence) (1); of sepsis only (consensus criteria) (0.50); none (0).

\section{Outcome measures}

The primary outcome measure was all cause mortality at 28 days. Secondary outcome measures included mortality in the intensive care unit and in hospital, number of patients with reversal of shock (that is, stable haemodynamic status for at least 24 hours after patients are weaned from vasopressors) at 7 and 28 days, and number of patients with adverse events (for instance, gastroduodenal bleeding, superinfections, hyperglycaemia, and other adverse effects).

\section{Search strategy for identification of studies}

We attempted to identify all relevant studies regardless of language or publication status (published, unpublished, either in press or in progress). We searched the Cochrane infectious diseases group's trials register for relevant trials up to August 2003 using the search terms sepsis and septic shock as described in the Cochrane Library (issue 3, 2003). We searched the Cochrane central register of controlled trials (Cochrane Library, issue 3, 2003) using the search terms sepsis, septic shock, steroids, and corticosteroids; Medline (1966 to August 2003) using the search terms sepsis, septic shock, steroids, corticosteroids, adrenal cortex hormones, and glucocorticoids; Embase
(1974 to August 2003) using the search terms sepsis, septic shock, steroids, and corticosteroids; and LILACS (to August 2003) using the search terms sepsis, steroids, and corticosteroids. ${ }^{16}$ We also checked the reference lists of resulting trials and, when possible, contacted authors to identify any additional published or unpublished data.

\section{Study selection}

One reviewer (DA) checked all identified titles and abstracts, and three reviewers (PEB, JB, and $\mathrm{DK}$ ) validated this check. Two pairs of reviewers (DA/PEB and JB/DK) examined all potential trials, selected eligible trials, and graded their methodological quality. Any disagreement within or between pairs was resolved by discussion within the four reviewers. We contacted authors for clarification when necessary.

\section{Assessment of methodological quality}

We documented the methodological quality of trials using a previously published score, ${ }^{8}$ and we graded generation of allocation sequence and allocation concealment as adequate, unclear, or inadequate. ${ }^{17}$ Methods for blinding were considered as double blind (neither patients nor care providers or assessors knew

\begin{tabular}{|c|c|c|c|}
\hline & Adequate & Inadequate & Unclear \\
\hline $\begin{array}{l}\text { Generation of allocation } \\
\text { concealment }\end{array}$ & $\begin{array}{l}\text { CSG 1963, Klasterski 1971, Sprung 1984, Bone } \\
\text { 1987, VASSCSG 1987, Luce 1988, Slusher 1996, } \\
\text { Bollaert 1998, Briegel 1999, Chawla 1999, Annane } \\
\text { 2002, Yildiz 2002, Keh } 2003\end{array}$ & Wagner 1955, Schumer 1976, Lucas 1984 & None \\
\hline Allocation concealment & $\begin{array}{l}\text { CSG 1963, Klasterski 1971, Bone 1987, VASSCSG } \\
\text { 1987, Luce 1988, Slusher 1996, Bollaert 1998, } \\
\text { Briegel 1999, Chawla 1999, Annane 2002, Yildiz } \\
\text { 2002, Keh } 2003\end{array}$ & $\begin{array}{l}\text { Wagner 1955, Schumer 1976, Lucas 1984, Sprung } \\
1984\end{array}$ & None \\
\hline Blinding & $\begin{array}{l}\text { Klasterski 1971, Bone 1987, VASSCSG 1987, Luce } \\
\text { 1988, Slusher 1996, Bollaert 1998, Briegel 1999, } \\
\text { Chawla 1999, Annane 2002, Yildiz 2002, Keh } 2003\end{array}$ & $\begin{array}{l}\text { Wagner 1955, CSG 1963, Schumer 1976, Lucas } \\
\text { 1984, Sprung } 1984\end{array}$ & None \\
\hline Lost to follow up & $\begin{array}{l}\text { Lucas 1984, VASSCSG 1987, Bollaert 1998, Briegel } \\
\text { 1999, Annane 2002, Keh } 2003\end{array}$ & None & $\begin{array}{l}\text { Wagner 1955, CSG 1963, Klasterski 1971, Schumer } \\
\text { 1976, Sprung 1984, Bone 1987, Luce 1988, Slusher } \\
\text { 1996, Chawla 1999, Yildiz } 2002\end{array}$ \\
\hline
\end{tabular}




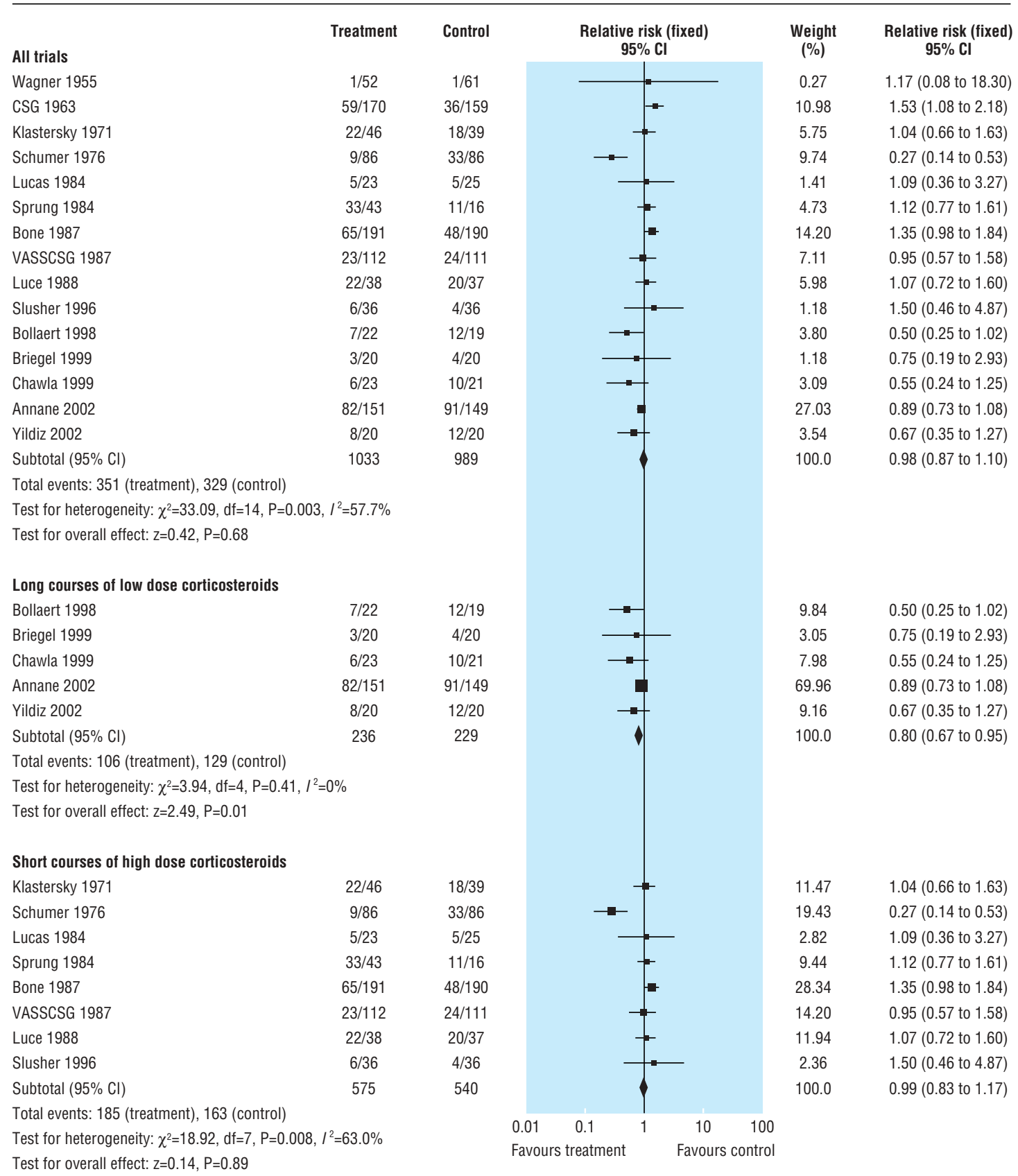

Fig 1 Effects of corticosteroids on all cause mortality at 28 days in patients with severe sepsis and septic shock

which treatment was given), single blind (either patients or care providers or assessors were aware of treatment), and open (all parties were aware of treatment). Loss to follow up was described as adequate (analysis included $\geq 90 \%$ of patients), unclear (not reported), and inadequate (analysis included $<90 \%$ of patients). Any disagreement within or between pairs was resolved by discussion within the four reviewers. We contacted authors for clarification when necessary.

\section{Data extraction}

One reviewer (DA) drew up a standard data extraction form and the other reviewers (PEB, JB, DK, and YK) validated it. Four reviewers (DA, PEB, JB, and DK) then independently extracted data and contacted authors of trials for missing data when possible. One reviewer (DA) entered data on to the computer, and four reviewers (PEB, JB, DK, and YK) checked them.

\section{Data analyses}

For each outcome measure, we computed $2 \times 2$ tables summarising, in each treatment group, the number of patients with the outcome and the total number of patients, and we organised the data so that a relative risk $<1.0$ favoured corticosteroids (except for shock reversal at days 7 and 28, for which $>1.0$ favoured corticosteroids). We performed intention to treat analyses. All statistical calculations used Review Manager 4.2. We calculated a weighted treatment effect (using fixed effects model) across trials. The results were expressed as relative risks with 95\% confidence intervals. We considered using random effects model only in case of heterogeneity (that is, $\mathrm{P} \leq 0.10$ for $\chi^{2}$ test for heterogeneity). 


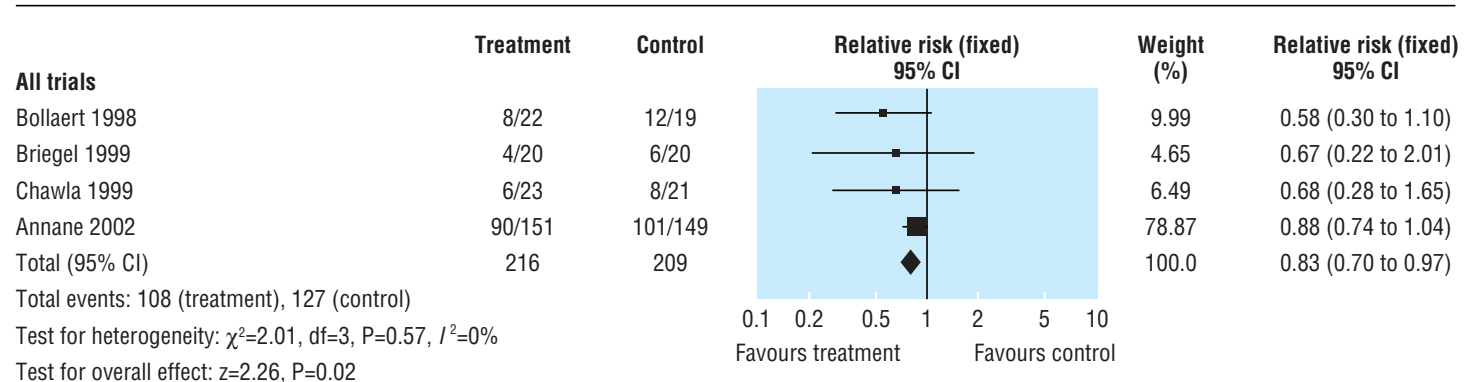

Fig 2 Effects of corticosteroids on mortality in intensive care unit in patients with severe sepsis and septic shock

Potential sources of heterogeneity were identified by sensitivity analyses on the basis of high quality trials and by subgroup analysis on the basis of long courses of low dose corticosteroids. This analysis allowed us to evaluate the strategy based on the high prevalence of adrenal insufficiency in septic shock and tested in trials performed after $1992 .{ }^{9-14}$ We sought evidence of publication bias using the funnel plot method. ${ }^{16}$

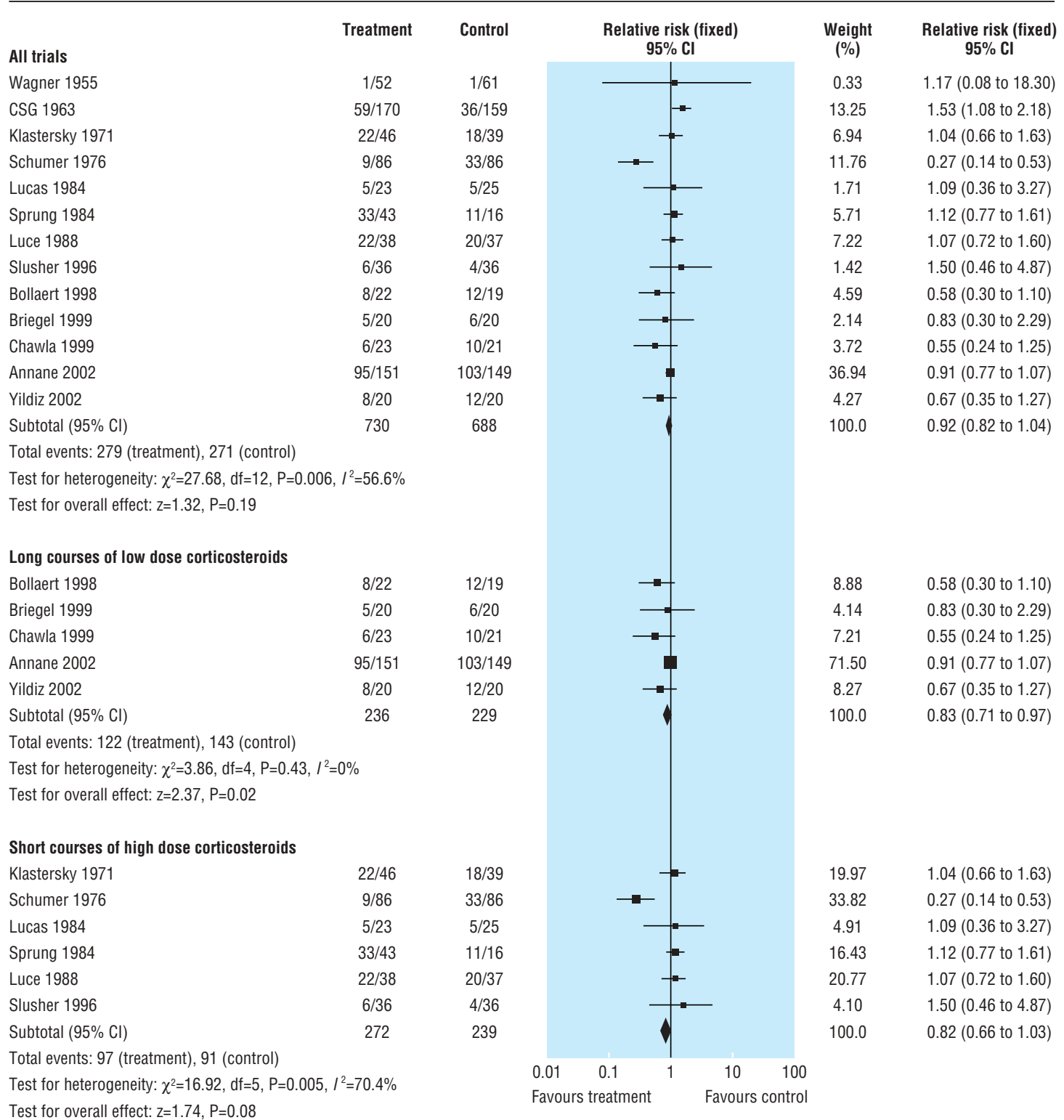

Fig 3 Effects of corticosteroids on mortality in hospital in patients with severe sepsis and septic shock 


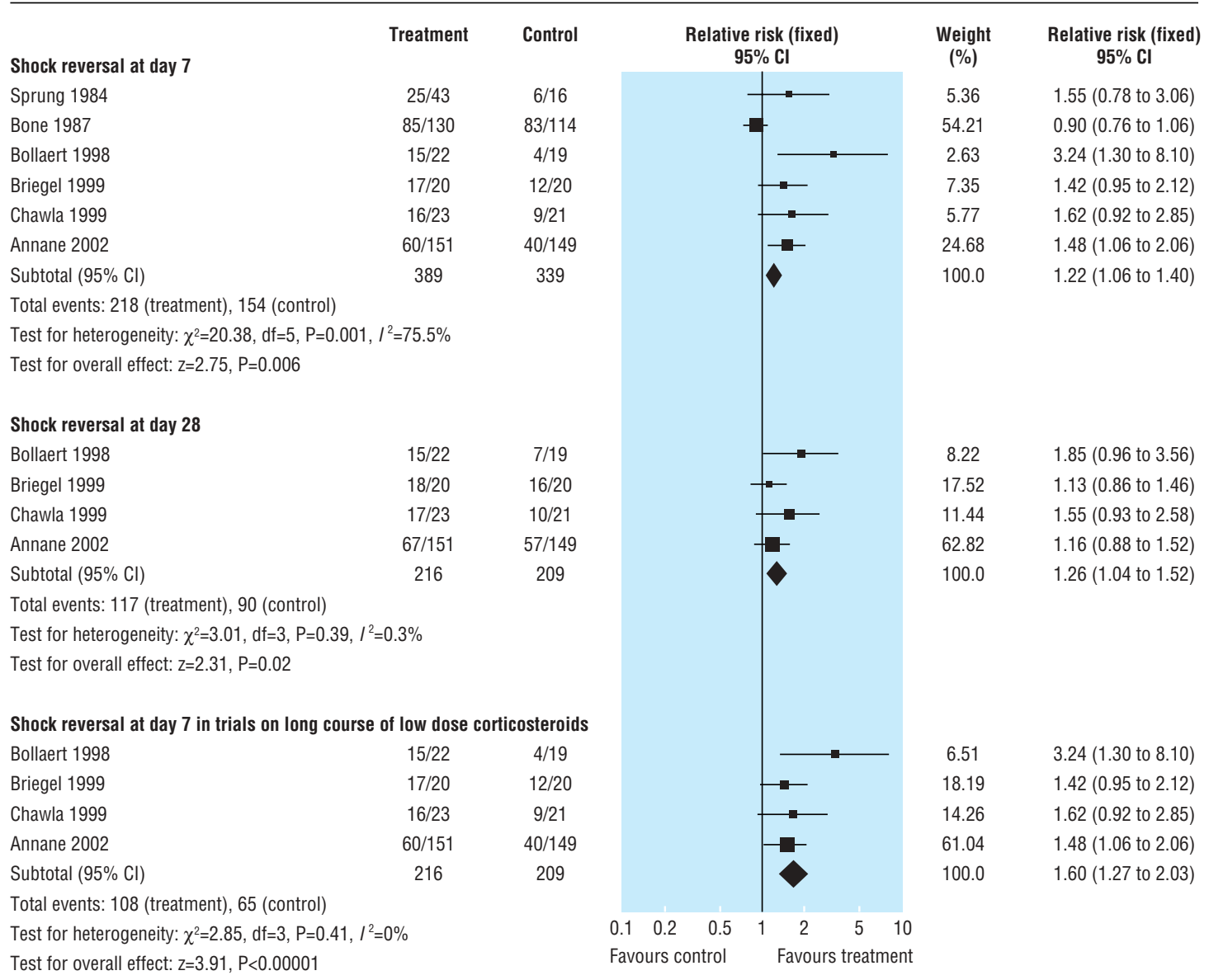

Fig 4 Effects of corticosteroids on shock reversal in patients with severe sepsis and septic shock

\section{Results}

\section{Description of studies}

We identified 23 trials on corticosteroids in severe sepsis or septic shock. ${ }^{9-1418-34}$ Of these, we excluded seven (table 1) ${ }^{18} 212225262934$ and included 16 trials $(\mathrm{n}=2063)$ (table 2$)$. For six trials $(\mathrm{n}=524)$ we extracted data from both published and unpublished souces. ${ }^{9-121428}$ For one trial, contact with authors did not provide any additional information. ${ }^{32}$ For the nine other trials the primary investigators could not be contacted..$^{13} 1920232427303133$ Tables 3 and 4 give details of the studies included.

\section{All cause mortality at $\mathbf{2 8}$ days}

We extracted data for all cause mortality at 28 days from 15 trials $(n=2022)$ (fig 1). There were 351/1033 (34\%) deaths in the treated group compared with 329/989 (33\%) in the control group. There was significant heterogeneity in the results $\left(\chi^{2}=33.09\right.$, $\mathrm{P}=0.003)$. The relative risk of dying at 28 days was $0.92(95 \%$ confidence interval 0.75 to $1.14, \mathrm{P}=0.46$; random effects model).

The subgroup analysis on five trials $(n=465)$ with long courses of low dose corticosteroids no longer showed heterogeneity across the trials, and the all cause mortality at 28 days was lower $(0.80,0.67$ to $0.95, \mathrm{P}=0.01)$. In contrast, the subgroup analysis on eight trials $(n=1115)$ with short courses of high dose corticosteroids did not show any difference $(0.97,0.72$ to 1.31 , $\mathrm{P}=0.84$; random effects model). Subgroup analyses based on high quality trials had a relative risk near 1.0 and failed to explain heterogeneity (data not shown).

\section{Mortality in intensive care unit}

We extracted data for mortality in intensive care units from four trials $(n=425)$, all of which investigated the effects of long courses of low dose corticosteroids (fig 2). There were 108/216 $(50 \%)$ deaths in the intensive care unit in the treated group compared with $127 / 209(61 \%)$ in the control group $(0.83,0.70$ to $0.97, \mathrm{P}=0.02$ ).

\section{Mortality in hospital}

We extracted data for hospital mortality from 13 trials $(n=1418)$ (fig 3). There were 279/730 (38\%) hospital deaths in the treated group compared with $271 / 688(39 \%)$ in the control group. There was significant heterogeneity in the results $\left(\chi^{2}=27.68\right.$, $\mathrm{P}=0.006)$. The relative risk of dying in hospital was 0.89 ( 0.71 to $1.11, \mathrm{P}=0.30$; random effects model).

The subgroup analysis on five trials $(\mathrm{n}=465)$ with long courses of low dose corticosteroids no longer showed heterogeneity across the trials and showed reduced mortality in hospital $(0.83,0.71$ to $0.97, \mathrm{P}=0.02)$. In contrast, the subgroup analysis on six trials $(n=511)$ with short courses of high dose corticosteroids did not show any difference in hospital mortality $(0.89,0.57$ to $1.37, \mathrm{P}=0.59$; random effects model). Subgroup analyses based on high quality trials had a relative risk near 1.0 and failed to explain heterogeneity (data not shown). 


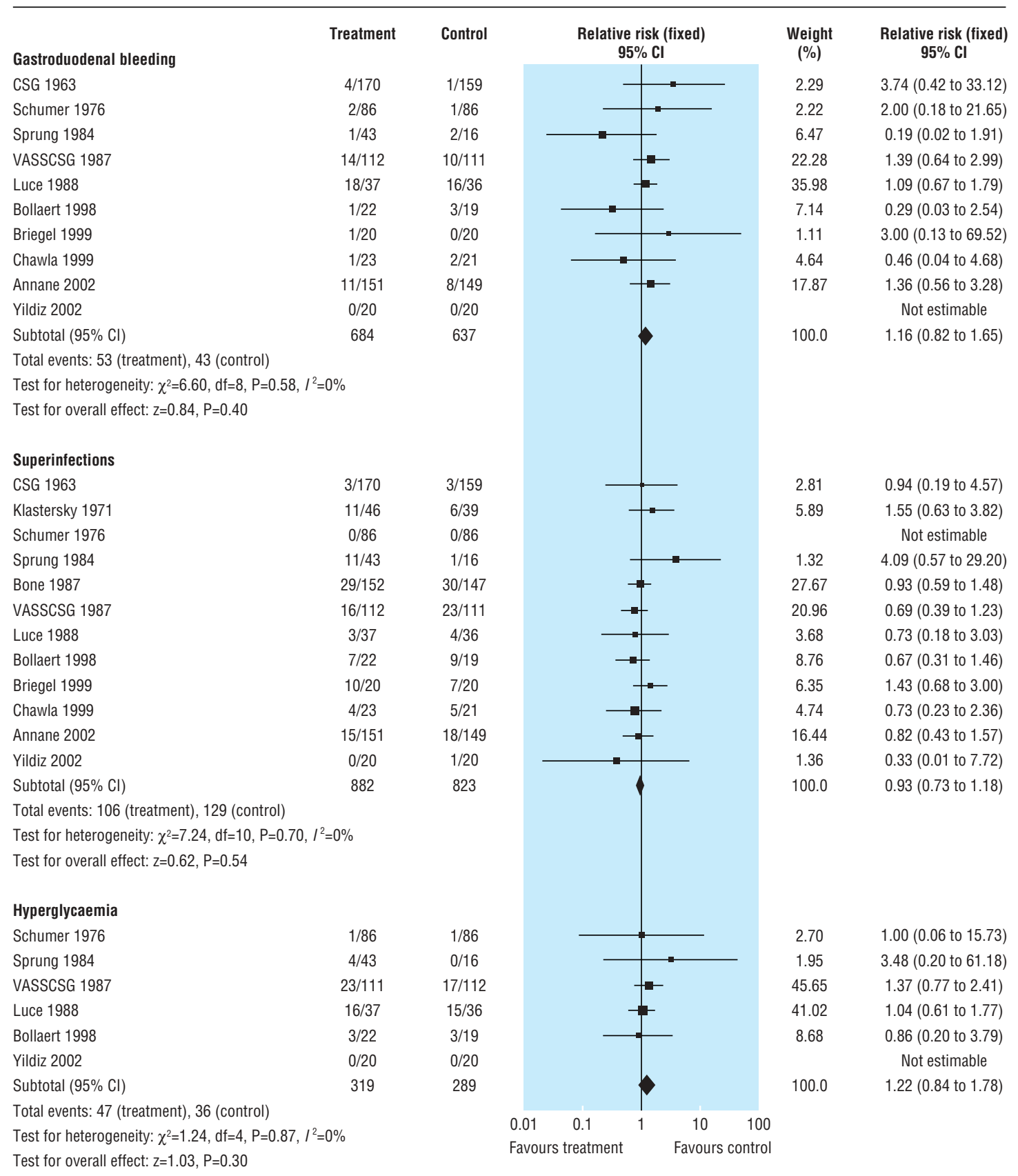

Fig 5 Adverse effects of corticosteroids in patients with severe sepsis and septic shock

Shock reversal at day 7

We extracted data for shock reversal at day 7 from six trials $(\mathrm{n}=728)$ (fig 4). There were 218/389 $(56 \%)$ shock reversals at day 7 in the treated group compared with $154 / 339(45 \%)$ in the control group (1.43, 1.01 to $2.01, \mathrm{P}=0.04$; random effects model). There was significant heterogeneity in the results $\left(\chi^{2}=20.38, \mathrm{P}=0.001\right)$.

The subgroup analysis on four trials $(\mathrm{n}=425)$ with long courses of low dose corticosteroids no longer showed heterogeneity across the trials, and showed increased rate of shock reversals at 7 days $(108 / 216(50 \%) v 65 / 209$ (31\%); 1.60, 1.27 to 2.03, $\mathrm{P}<0.0001)$

\section{Shock reversal at day 28}

We extracted data for shock reversal at day 28 from four trials $(\mathrm{n}=425)$ (fig 4). There were $117 / 216(54 \%)$ shock reversals at day 28 in the treated group compared with 90/209 (43\%) in the control group $(1.26,1.04$ to $1.52, \mathrm{P}=0.02)$.

\section{Adverse events}

There was no evidence that corticosteroids increased the risk of gastroduodenal bleeding ( 10 trials, $\mathrm{n}=1321 ; 1.16,0.82$ to 1.65 , $\mathrm{P}=0.40$ ), superinfections ( 12 trials, $\mathrm{n}=1705 ; 0.93,0.73$ to 1.18 , $\mathrm{P}=0.54$ ), or hyperglycaemia ( 6 trials, $\mathrm{n}=608 ; 1.22,0.84$ to 1.78 , $\mathrm{P}=0.30$ ) (fig 5). Only one trial reported the definition for hyperglycaemia, ${ }^{32}$ the others reporting only the number of patients with hyperglycaemia. Another trial reported a significant rise in serum sodium concentration $(>155 \mathrm{mmol} / \mathrm{l})$ in $6 / 20(30 \%)$ patients in the treated group and in $1 / 20(5 \%)$ patients in the placebo group. ${ }^{10}$ 


\section{Discussion}

When we considered all the trials included in this systematic review, regardless of duration of treatment and dose, we found no evidence of a beneficial effect of corticosteroids on all cause mortality at 28 days and mortality in hospital from severe sepsis and septic shock. However, for both outcomes, the results showed strong heterogeneity that was not explained by the quality of the trials. For both outcomes, sorting the trials by year of publication showed that before 1992 almost all trials showed a relative risk of dying $>1.0$, whereas after 1992 all trials had a relative risk of dying $<1.0$. This date coincides with the consensus definition for sepsis ${ }^{15}$ and with the observation that septic shock is often complicated by adrenal insufficiency. ${ }^{35}$ The trials conducted before 1992 probably included patients with a heterogeneous risk of death, while the trials designed after 1992 focused on a more homogeneous population of patients with septic shock. More recent trials also used long courses of low dose corticosteroids, with the aim of treating adrenal insufficiency $^{535}$ or because of cortisol tissue resistance. ${ }^{6}$ The preferred drug was hydrocortisone, with doses of 200-300 mg used to reproduce the cortisol concentrations achieved at maximum exercise in healthy people. ${ }^{910}{ }^{14}$ Treatment lasted about a week, corresponding roughly to the mean time that patients with septic shock take vasopressors. Sensitivity analyses of these trials showed significant reduction in all cause mortality at 28 days and mortality in hospital. Long courses of low dose corticosteroids also reduced mortality in intensive care units.

Improvement in survival with corticosteroids may result from reduced duration of shock (as shown by the higher proportions of shock reversal at days 7 and 28), severity of inflammation, ${ }^{14}$ and number of organ dysfunctions..$^{10} 14$ The benefits we have shown are in line with findings from studies on animals, isolated vascular smooth muscles, and inflammatory cells and on healthy volunteers challenged with endotoxin. ${ }^{4}$ Indeed, studies consistently showed that corticosteroids improved vessels' contractility and haemodynamics; prevented inflammatory cells' recruitment, proliferation, and release of pro-inflammatory mediators; and improved survival from all types of animal models of sepsis. ${ }^{4}$ Finally, there was no evidence of increased rates of gastroduodenal bleeding, superinfections, or hyperglycaemia associated with the use of corticosteroids.

There were differences between the six trials conducted after 1992. One trial included both severe sepsis and septic shock, ${ }^{13}$ whereas the others included only septic shock. One trial allowed concomitant therapies with anti-thrombin III or intravenous polyclonal immunoglobulins,${ }^{10}$ and the others did not. The time on shock before randomisation was also different: one trial included only early septic shock, ${ }^{12}$ two included late septic shock, ${ }^{911}$ and two included both early and late septic shock. ${ }^{10}{ }^{14}$

\section{Strengths of study}

Because of our comprehensive search strategy, omission of important trials seems unlikely. We included 16 trials, but the outcomes foreseen for this review were not available in one crossover trial. ${ }^{14}$ This trial showed short term improved haemodynamic and immune outcomes with a low dose of hydrocortisone. We considered it acceptable in a meta-analysis to pool the results from the 15 remaining trials. We converted outcome measures corresponding to censored data into dichotomous variables - that is, proportion of patients with an event after one and four weeks or in the intensive care unit or at hospital discharge.
What is already known

Short courses of high dose corticosteroids do not affect mortality from severe sepsis and septic shock

Long courses of low dose corticosteroids improve systemic haemodynamics and reduce the time on vasopressor treatment

\section{What this paper adds}

Long courses of low dose corticosteroids reduce mortality at 28 days, in intensive care units, and in hospital

Long courses of low dose corticosteroids do not significantly alter the risk of gastroduodenal bleeding, superinfections, or hyperglycaemia

\section{Recommendations}

We cannot provide definite recommendations for the selection of patients who might most benefit from corticosteroid. Separate data for adrenal insufficiency were available in only two studies. ${ }^{912}$ However, different definitions for adrenal insufficiency were used. In the first trial, too few patients had adrenal insufficiency to draw any conclusion. ${ }^{9}$ In the second trial, a benefit from corticosteroids was shown only in patients with a cortisol increase after adrenocorticotropin hormone $\leq 248 \mathrm{nmol} / 1 .{ }^{12}$ The weight of this trial in the meta-analysis was about $70 \%$. Until there is further research on optimising diagnostic testing of adrenal insufficiency in patients with septic shock, corticosteroids should be given only to patients with a random cortisol concentration $\leq 414 \mathrm{nmol} / \mathrm{l}$ (that is, absolute adrenal insufficiency) or a cortisol response to adrenocorticotropin hormone $\leq 248$ $\mathrm{nmol} / \mathrm{l}$ (that is, relative adrenal insufficiency). ${ }^{36}$

In conclusion, hydrocortisone (or equivalent) should be given to patients with septic shock immediately after they undergo an adrenocorticotropin hormone test, at a dose of 200$300 \mathrm{mg}$, and should be continued for 5-11 days, only when absolute or relative adrenal insufficiency is present.

A longer version of this review has been published in the Cochrane Library. ${ }^{37}$

Contributors: All authors were involved in study concept, design, and critical revision for important intellectual content. DA, PEB, JB, DK, and YK were responsible for acquisition of data. DA, PEB, JB, and DK analysed and interpreted the data. DA and EB drafted the review. DA is guarantor.

Funding: Hôpital Raymond Poincaré, Garches, France. UK Department for International Development.

Competing interests: Authors of this review have been involved in randomised controlled trials of low dose hydrocortisone that are included in this review.

Ethical approval: Not required.

1 Angus D, Linde-Zwirble WT, Lidicker J, Clermont G, Carcillo J, Pinsky MR. Epidemiology of severe sepsis in the United States: analysis of incidence, outcome, and associated ogy of severe sepsis in the United States: analysi
costs of care. Crit Care Med 2001;29:1303-10.

2 Rangel-Frausto MS, Pittet D, Hwang T, Woolson RF, Wenzel RP. The dynamics of disease progression in sepsis: Markov modeling describing the natural history and the likely impact of effective antisepsis agents. Clin Infec Dis 1998;27:185-90.

3 Annane D, Aegerter P, Jars-Guincestre MC, Guidet B. Current epidemiology of septic shock: the CUB-Réa Network. Am J Resp Crit Care Med 2003;168:165-72.

4 Annane D, Cavaillon JM. Corticosteroids in sepsis: from bench to bedside? Shock 2003;20:197-207.

5 Annane D, Sébille V, Troché G, Raphael JC, Gajdos P, Bellissant E. A 3-level prognostic classification in septic shock based on cortisol levels and cortisol response to corticotrophin. JAMA 2000;283:1038-45.

6 Meduri GU, Chrousos GP. Duration of glucocorticoid treatment and outcome in sepsis: is the right drug used the wrong way? Chest 1998;114:355-60.

7 Lefering R, Neugebauer EAM. Steroid controversy in sepsis and septic shock: a metaLefering R, Neugebauer EAM. Steroid con
analysis. Crit Care Med 1995;23:1294-303.

8 Cronin L, Cook DJ, Carlet J, Heyland DK, King D, Lansang MA, et al. Corticosteroid treatment for sepsis: a critical appraisal and meta-analysis of the literature. Crit Care Med 1995;23:1430-9. 
9 Bollaert PE, Charpentier C, Levy B, Debouverie M, Audibert G, Larcan A. Reversal of late septic shock with supraphysiologic doses of hydrocortisone. Crit Care Med 1998;26:645-50

10 Briegel J, Forst H, Haller M, Schelling G, Kilger E, Kuprat G, et al. Stress doses of hydrocortisone reverse hyperdynamic septic shock: a prospective, randomized, doubleblind, single-center study. Crit Care Med 1999;27:723-32.

11 Chawla K, Kupfer Y, Tessler S. Hydrocortisone reverses refractory septic shock. Crit Care Med 1999;27:A33.

12 Annane D, Sebille V, Charpentier C, Bollaert PE, Francois B, Korach JM, et al. Effect of treatment with low doses of hydrocortisone and fludrocortisone on mortality in patients with septic shock. JAMA 2002;288:862-71.

13 Yildiz O, Doganay M, Aygen B, Guven M, Keleutimur F, Tutuu A. Physiologic-dose steroid therapy in sepsis. Crit Care 2002;6:251-9.

14 Keh D, Boehnke T, Weber-Cartens S, Schulz C, Ahlers O, Bercker S, et al. Immunologic and hemodynamic effects of "low-dose" hydrocortisone in septic shock: a double-blind, randomized, placebo-controlled, crossover study. Am J Resp Crit Care Med 2003; $167: 512-0$

15 American College of Chest Physicians/Society of Critical Care Medicine Consensus Conference. Definitions for sepsis and organ failure and guidelines for the use of innovative therapies in sepsis. Crit Care Med 1992;20:864-74

16 Clarke M, Oxman A, eds. Cochrane reviewers'handbook 4.2.0 [updated March 2003]. In: The Cochrane Library. Issue 3. Chichester: John Wiley, 2003.

17 Juni P, Altman DG, Egger M. Systematic reviews in healthcare: assessing the quality of controlled clinical trials. BMJ 2001;323:42-6.

18 Hahn EO, Houser HB, Rammelkamp CH Jr, Denny FW, Wannamaker LW. Effect of cortisone on acute streptococcal infections and poststreptococcal complications. J Clin
chent Invest 1951:30:274-81.

19 Wagner HN, Bennett IL, Lasagna L, Cluff LE, Rosenthal MB, Mirick GS. The effect of hydrocortisone upon the course of pneumococcal pneumonia treated with penicillin. Bull Johns Hopkins Hosp 1955;98:197-215.

20 Cooperative Study Group. The effectiveness of hydrocortisone in the management of severe infections. JAMA 1963;183:462-5.

21 Rogers J. Large doses of steroids in septicaemic shock. Br J Urol 1970;42:742.

22 Thompson WL, Gurley HT, Lutz BA, Jackson DL, Kvols LK, Morris IA. Inefficacy of glucocorticoids in shock (double-blind study). Clin Res 1976;24:258A

23 Klastersky J, Cappel R, Debusscher L. Effectiveness of betamethasone in managemen of severe infections. A double-blind study. N Engl J Med 1971;284:1248-50.

24 Schumer W. Steroids in the treatment of clinical septic shock. Ann Surg 1976;184:333Sch.

25 McKee JI, Finlay WE. Cortisol replacement in severely stressed patients. Lancet $1983 ; 1: 484$

26 Hughes GS Jr. Naloxone and methylprednisolone sodium succinate enhance sympathomedullary discharge in patients with septic shock. Life Sci 1984;35:2319-26.

27 Lucas C, Ledgerwood A. The cardiopulmonary response to massive doses of steroids in patients with septic shock. Arch Surg 1984;119:537-41

28 Sprung CL, Caralis PV, Marcial EH, Pierce M, Gelbard MA, Long WM, et al. The effects of high-dose corticosteroids in patients with septic shock. A prospective, controlled study. N Engl J Med 1984;311:1137-43.

29 Weigelt JA, Norcross JF, Borman KR, Snyder WH 3rd. Early steroid therapy for respiratory failure. Arch Surg 1985;120:536-40.
30 Bone RG, Fisher CJ, Clemmer TP, Slotman GJ, Metz CA, Balk RA. A controlled clinical rial of high-dose methylprednisolone in the treatment of severe sepsis and septic hock. N Engl J Med 1987;317:653-8

31 Veterans Administration Systemic Sepsis Cooperative Study Group. Effect of high-dose glucocorticoid therapy on mortality in patients with clinical signs of systemic sepsis. N EnglJ Med 1987;317:659-65.

32 Luce JM, Montgomery AB, Marks JD, Turner J, Metz CA, Murray JF. Ineffectiveness of high-dose methylprednisolone in preventing parenchymal lung injury and improving mortality in patients with septic shock. Am Reu Resp Dis 1988:138:62-8.

33 Slusher T, Gbadero D, Howard C, Lewison L, Giroir B, Toro L, et al. Randomized, placebo-controlled, double blinded trial of dexamethasone in African children with sepsis. Ped Infect Dis J 1996;15:579-83.

34 Meduri GU, Headley AS, Golden E, Carson SJ, Umberger RA, Kelso T, et al. Effect of prolonged methylprednisolone therapy in unresolving acute respiratory distress syndrome: a randomized controlled trial. JAMA 1998;280:159-65.

35 Rothwell PM, Udwadia ZF, Lawler PG. Cortisol response to corticotropin and survival in septic shock. Lancet 1991;337:582-3.

36 Cooper MS, Stewart PM. Corticosteroid insufficiency in acutely ill patients. $N$ Engl $J$ Med 2003;348:727-34.

37 Annane D, Bellissant E, Bollaert P, Briegel J, Keh D, Kupfer Y. Corticosteroids for treating severe sepsis and septic shock. Cochrane Database Syst Rev 2004;(1):CD002243.

(Accepted 16June 2004)

doi $10.1136 /$ bmj.38181.482222.55

Critical Care Department, Université de Versailles Saint-Quentin en Yvelines, Assistance Publique-Hôpitaux de Paris, Hôpital Raymond Poincaré, Garches 92380, France

Djillali Annane professor of intensive care medicine

Clinical Investigation Centre, INSERM 0203, Université de Rennes 1, Centre

Hospitalier Universitaire, Hôpital de Pontchaillou, Rennes 35033, France

Eric Bellissant professor of clinical pharmacology

Critical Care Department, Université de Nancy 1, Centre Hospitalier Universitaire,

Hôpital Central, Nancy 54000, France

Pierre Edouard Bollaert professor of intensive care medicine

Institut für Anaesthesiology, Klinikum der Universität München, Munich, 81366, Germany

Josef Briegel professor of anaesthesiology and intensive care medicine

Intensive Care Unit, Charité-Campus Virchow Clinic, Berlin, 13353, Germany Didier Keh attending physician

Division of Pulmonary and Critical Care Medicine, Maimonides Medical Centre, Brooklyn, New York, NY 11219, USA

Yizhak Kupfer attending physician

Correspondence to: D Annane djillali.annane@rpc.ap-hop-paris.fr 